\title{
KONSEP DIRI AKADEMIK PESERTA DIDIK JENJANG MENENGAH PERTAMA BERDASARKAN JENIS KELAMIN (Studi Survei di Lembaga Bimbingan Belajar Primagama Kampung Makasar)
}

\author{
Sholikhin ${ }^{1}$ \\ Meithy Intan R. Luawo ${ }^{2}$ \\ Djunaedi $^{3}$
}

\begin{abstract}
Abstrak
Penelitian ini bertujuan untuk memperoleh data empirik profil konsep diri akademik peserta didik berdasarkan jenis kelamin. Penelitian dilaksanakan di Primagama Kampung Makasar, dengan sampel seluruh peserta didik jenjang menengah pertama yang mengikuti program bimbingan belajar di Lembaga Bimbingan Belajar Primagama Kampung Makasar. Sampel diambil dengan menggunakan teknik sampel jenuh. Pengumpulan data dilakukan dengan menggunakan kuesioner dan dianalisis dengan menggunakan analisis deskriptif. Konsep diri akademik peserta didik lakilaki berada pada kategori tinggi sebesar 18,18\% dengan jumlah responden 4 orang dari total 22 orang peserta didik laki-laki, $68,18 \%$ termasuk kedalam kategori sedang atau sejumlah 15 orang peserta didik, $13,64 \%$ peserta didik laki-laki termasuk kedalam kategori rendah atau sejumlah 3 orang. Peserta didik perempuan yang berada pada kategori tinggi dengan persentase $20 \%$ atau sebanyak 3 orang, kategori sedang berjumlah 11 orang atau sebesar $73,33 \%$, kategori rendah sejumlah 1 orang atau sebesar $6,67 \%$. Kesimpulan yang diperoleh secara umum peserta didik lakilaki secara mayoritas memiliki konsep diri akademik sedang atau rata-rata dengan mencapai $68,18 \%$. Peserta didik perempuan juga mayoritas berada pada kategori sedang sebesar $73,33 \%$.
\end{abstract}

Kata Kunci: Konsep Diri Akademik, Jenis Kelamin.

\section{PENDAHULUAN}

Konsep Diri Akademik merupakan suatu persepsi diri seseorang mengenai kemampuan akademiknya yang dipengaruhi oleh pengalaman pribadi dan interaksi dengan lingkungannya.

Sehingga peserta didik yang memiliki konsep diri yang baik, akan berusaha agar senantiasa mengembangkan potensi yang dimiliki termasuk potensi untuk belajar dengan baik agar mendapatkan nilai yang cukup memuaskan.

Peserta didik jenjang menengah pertama, memiliki tuntutan yang cukup besar saat ini, terutama dalam kurikulum 2013 yang mewajibkan lulusan dari SMP/MTS sederajat harus sudah siap untuk menentukan kemanakah mereka akan melanjutkan sekolah, SMA atau SMK, serta jurusan atau konsentrasi bidang yang akan mereka pelajari selama di SMA/SMK sejak awal pendaftaran. Sehingga peserta didik jenjang menengah pertama harus sudah memahami potensi yang dimiliki dan tujuan melanjutkan pendidikan mereka kemana.

Persaingan antar lulusan jenjang menengah pertama sangat ketat, mereka harus memperebutkan kursi di SMA/SMK

\footnotetext{
${ }^{1}$ Mahasiswa Program Studi Bimbingan dan Konseling FIP UNJ, ikhin.sholikhin@gmail.com

${ }^{2}$ Dosen Program Studi Bimbingan dan Konseling FIP UNJ

${ }^{3}$ Dosen Program Studi Bimbingan dan Konseling FIP UNJ
} 
negeri dengan menggunakan nilai UN mereka dan didukung dengan prestasi akademik/ non-akademik lainnya. Sekolah menuntut seluruh peserta didik dapat menguasai semua kompetensi yang diajarkan dalam bidang pelajaran yang ada di sekolah.

Sehingga banyak peserta didik yang mengikuti program belajar di lembaga bimbingan belajar dan diharapkan dapat lebih mengoptimalkan kemampuan yang dimiliki untuk meraih prestasi terbaik.

Berdasarkan studi pendahuluan yang dilakukan di Primagama Kampung Makasar menunjukkan adanya tingkat variasi dalam hal kemampuan akademik, kualitas sekolah, pencapaian akademik, dan latar belakang peserta didik. Selain itu, Primagama ini juga memiliki perbedaan dalam pengaturan penentuan kelas yang dipilih oleh peserta didik. Sehingga kemampuan peserta didik bisa dilihat dari kelas yang mereka ikuti, misalnya untuk jenjang kelas 6 SD terdapat kelas reguler dan excellent. Jika di kelas reguler terdapat maksimal 15 peserta didik, di kelas excellent hanya ada maksimal 5 peserta didik saja. Sementara di kelas 9 SMP sendiri terdapat 2 kelas berbeda yaitu 9 SMP 1 dan 9 SMP 2 yang dibedakan atas kemampuan mereka dalam menyerap pelajaran, sementara untuk kelas 7 dan 8 hanya memiliki satu kelas. Pada kelas 9 SMP 1 mayoritas adalah peserta didik yang memiliki kemampuan akademis yang baik dan peserta didiknya juga lebih tertib, sedangkan di kelas 9 SMP 2 mayoritas diisi oleh peserta didik yang memiliki kemampuan akademis kurang sehingga membutuhkan perhatian lebih dan membutuhkan jam tambahan untuk bisa menyerap materi dengan lebih optimal. Pada kelas 7 dan 8, kemampuan peserta didiknya bervariasi sehingga tingkat persaingan untuk menjadi yang terbaik di kelas sangat terasa.

Dengan terlihatnya masalah yang sudah di uraikan di atas, maka peniliti tertarik untuk melakukan penelitian mengenai konsep diri akademik peserta didik jenjang menengah pertama berdasarkan jenis kelamin.

Tujuan penelitian ini adalah untuk mengetahui data empirik profil konsep diri akademik yang dimiliki oleh peserta didik jenjang menengah pertama Primagama Kampung Makasar berdasarkan jenis kelamin.

\section{KAJIAN TEORI SELF-CONCEPT}

Self-concept atau lebih dikenal sebagai konsep diri bermula dari seorang tokoh yang bernama William James yang membedakan dua aspek mendasar dari self, yaitu "I" dan "Me". Menurut James dalam Burns (1982) konsep "I" menunjuk pada individu sebagai subjek dan "Me" menunjuk individu sebagai objek. Konsep "I" sebagai diri yang mengetahui atau knower dan "Me" sebagai diri yang diketahui. Konsep "Me" inilah yang disebut sebagai self-concept. Konsep "I" disebutjuga dengan subjectiveself karena aspek inilah yang mengorganisasikan serta menginterpretasikan pengalaman seseorang. Sementara itu, "Me" disebut juga sebagai objective self atau impirical self karena aspek ini merupakan ciptaan dari "I".

Sementara itu, Shavelson (1982) mendefinisikan Self-concept sebagai suatu bagian dari kepribadian manusia yang tercermin dari bagaimana seseorang memandang dirinya sendiri dari sudut pandang yang dia miliki. Self-concept secara umum dapat didefinisikan sebagai cara seseorang mempersepsikan dirinya sendiri. Persepsi ini dipengaruhi oleh beberapa hal antara lain pengaruh lingkungan dan dorongan dari orang-orang sekitarnya. Seseorang memiliki self-concept yang baik, akan menunjukkan kepercayaan diri yang baik pula. Hal ini disebabkan karena selfconcept merupakan salah satu unsur yang membangun kepercayaan diri seseorang

\section{KONSEP DIRI AKADEMIK}

Menurut O'Mara dalam Rosen (2010) mendefinisikan konsep diri akademik secara umum sebagai persepsi diri siswa terhadap kemampuan akademiknya yang dibentuk oleh pengalaman pribadi dan interaksi dengan lingkungan. 
Menurut Lent dalam Bacon (2011) Konsep diri akademik juga dapat diartikan sebagai sikap spesifik, perasaan dan persepsi terhadap kemampuan intelektual seseorang atau kemampuan akademik, yang menggambarkan percaya diri seseorang dan self-feelings seseorang dalam ranah akademik.

Menurut Marsh (1990), secara umum konsep diri akademik dibagi atas 2 aspek dan 9 indikator, hal ini merupakan hasil pengembangan dari Shavelson, Hubner dan Stanton model pada tahun 1976 yang membagi konsep diri akademik secara umum menjadi 4 aspek saja yaitu Math S.C, English S.C, History S.C, dan Science S.C. Aspek yang dikembangkan oleh Marsh antara lain Math academic self-concept dan Verbal academic self concept. Kemudian 9 indikator dari aspek-aspek tersebut antara lain Math Self-Concept (S.C.), Physical Science S.C., Biological Science S.C., Economics Business S.C., School S.C., Geography S.C., History S.C., Foreign Languages S.C., dan English S.C.

Kemudian pada tahun 1992, Marsh mengembangkan kembali teori mengenai Konsep diri akademik secara lebih spesifik lagi. Pada perkembangannya, Konsep diri akademik menurut Marsh terdiri atas 17 skala yang terbagi dalam 9 core subject matter subscales, 6 non-core subject subscales, dan 1 Physical subscales. Kemudian Marsh menjadikan skala tersebut sebagai bahan pengukuran bagi konsep diri akademik melalui alat pengukuran bernama Academic Self Description Questionnaire II (ASDQ II). Adapun faktor yang ada dalam ASDQ II dapat dilihat dalam tabel dibawah ini:

Tabel 1

ASDQ II Factors

\begin{tabular}{ll}
\hline \multicolumn{1}{c}{ Factor } & \multicolumn{1}{c}{ Description } \\
\hline Computer Studies & Core Subjects \\
English Language & \\
History & \\
Mathematics & \\
English Literature & \\
Science & \\
Commerce & \\
Geography & \\
Foreign Language &
\end{tabular}

Physical Education

Art

Music

Industrial Art

Religious Studies

Health

$\begin{array}{ll}\text { Physical } & \text { Physical } \\ \text { School Subject } & \text { General School }\end{array}$

Berdasarkan teori yang dikembangkan oleh Marsh, kemudian peneliti melakukan adaptasi dengan mengubah faktor yang ada dalam ASDQ II sesuai dengan kurikulum yang ada di Indonesia. Sehingga peneliti memperoleh 4 pelajaran inti dan 7 pelajaran Non-Inti sebagaimana terdapat pada tabel di bawah ini:

Tabel 2

ASDQ II (Adaptasi Kurikulum Indonesia)

\begin{tabular}{ll}
\hline \multicolumn{1}{c}{ Faktor } & \multicolumn{1}{c}{ Deskripsi } \\
\hline Bahasa Indonesia & \\
Bahasa Inggris & \\
Ilmu Pengetahuan Alam Pelajaran Inti \\
(IPA) \\
Matematika \\
\hline
\end{tabular}

Faktor Deskripsi

Bimbingan dan Konseling

(BK)

Ilmu Pengetahuan Sosial

(IPS)

Pendidikan Agama

Pendidikan Kewarganegaraan $(\mathrm{PKN})$

Pendidikan Jasmani, Olah

Pelajaran Non-Inraga dan Kesehatan (Penjasorkes)

Seni Budaya

Teknologi Informasi dan Komunikasi (TIK) 


\begin{tabular}{ll}
\hline Fisik & Fisik \\
Pelajaran Khas Sekolah & Muatan Lokal \\
\hline
\end{tabular}

\section{METODOLOGI PENELITIAN}

Metode Penelitian ini merupakan penelitian deskriptif dengan menggunakan pendekatan kuantitatif. Metode penelitian yang digunakan dalam penelitian ini adalah metode survei. Jenis penelitian yang digunakan dalam penelitian ini adalah penelitian deskriptif.

Populasi penelitian ini sebanyak 37 orang yang terdiri dari 7 orang peserta didik kelas 7, 11 orang peserta didik kelas 8 , dan 19 orang peserta didik kelas 9. Sampel yang digunakan dalam penelitian ini adalah menggunakan sampling jenuh atau sensus sehingga seluruh anggota populasi digunakan sebagai sampel

Teknik pengumpulan data yang digunakan dalam penelitian ini adalah teknik nontes dengan menggunakan instrumen kuesioner. Instrumen yang digunakan dalam penelitian ini adalah Academic Self Description Questionnaire II untuk mengukur konsep diri akademik. Instrumen ini dikembangkan oleh Marsh dan skala yang digunakan untuk mengukur variabel yaitu skala model Thurstone.

Teknik analisis data yang digunakan dalam penelitian ini adalah analisa data deskriptif.

\section{HASIL DAN PEMBAHASAN}

Tujuan yang ingin dicapai dari penelitian ini adalah untuk mendapatkan data empiris mengenai profil konsep diri akademik yang dimiliki oleh peserta didik jenjang menengah pertama Primagama Kampung Makasar berdasarkan jenis kelamin.

Kelompok penelitian dibagi menjadi 2 yaitu peserta didik laki-laki dan perempuan. peserta didik laki-laki pada jenjang menengah pertama yang mengikuti program bimbingan belajar di Lembaga Bimbingan Belajar Primagama Kampung Makasar adalah sejumlah 22 anak dan peserta didik perempuan sejumlah 15 anak.
Data ini diperoleh dari kuesioner yang diberikan kepada responden laki-laki sebanyak 22 peserta didik. Berdasarkan pengolahan data, diperoleh skor minimal 464, skor maksimal 823 , rata-rata 627,86 , median 624,5 , modus 6 , simpangan baku 82,90 dan varian 6872,31 .

Tabel 3

Distribusi Frekuensi Skor Konsep Diri Akademik Peserta Didik Laki-Laki

\begin{tabular}{lccc}
\hline & Interval & Jumlah & Persentase \\
\hline Tinggi & $>711$ & 4 & 18,18 \\
Sedang & $545-711$ & 15 & 68,18 \\
Rendah & $<545$ & 3 & 13,64 \\
\hline
\end{tabular}

Berdasarkan tabel kategorisasi diatas, diketahui bahwa konsep diri akademik peserta didik laki-laki berada pada kategori tinggi sebesar $18,18 \%$ dengan jumlah responden 4 orang dari total 22 orang peserta didik laki-laki untuk jenjang menengah pertama di Primagama Kampung Makasar. Hal ini menunjukkan bahwa sebagian kecil saja peserta didik laki-laki yang memiliki konsep diri akademik sangat baik atau termasuk dalam kategori tinggi. Peserta didik yang termasuk dalam kategori tinggi adalah peserta didik yang mendapatkan skor total lebih dari 711.

Terdapat sekitar $13,64 \%$ peserta didik laki-laki yang memperoleh skor total dibawah 545 sehingga termasuk kedalam kategori rendah. Jumlah peserta didik yang termasuk dalam kategori rendah adalah sejumlah 3 orang. Sementara itu, peserta didik lakilaki mayoritas berada pada kategori sedang atau dengan kata lain peserta didik laki-laki memiliki konsep diri akademik rata-rata yaitu sekitar $68,18 \%$ atau sekitar 15 orang peserta didik. Adapun skor total untuk kategori ini adalah diantara 545 dan 711 . Mean atau ratarata yang diperoleh peserta didik laki-laki adalah sebesar 627,86. Kategorisasi konsep diri akademik peserta didik laki-laki dapat pula digambarkan melalui diagram dibawah ini:

Grafik 1

Persentase Konsep Diri Akademik Peserta Didik 


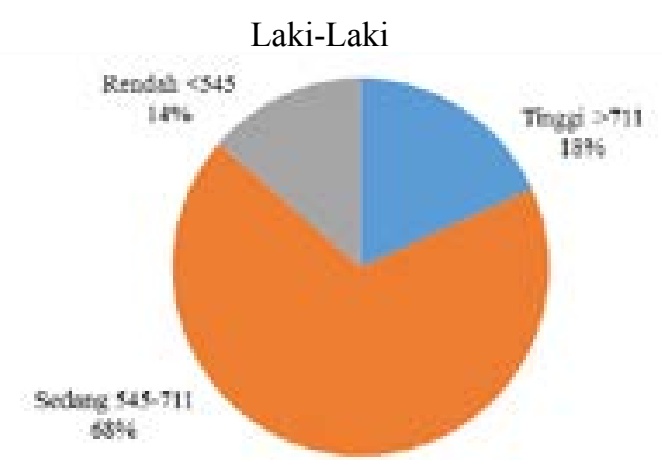

Data diperoleh dari kuesioner yang diberikan kepada responden 15 peserta didik perempuan. Berdasarkan pengolahan data diperoleh skor minimal 474, skor maksimal 747 , rata-rata 643,6 , median 690 , modus 7 , simpangan baku 86,94 dan varian 7559,4 .

Tabel 4

Distribusi Frekuensi Skor Konsep Diri Akademik Peserta Didik Perempuan

\begin{tabular}{lccc}
\hline & & Jumlah & Persentase \\
\cline { 3 - 4 } Tinggi & $>731$ & 3 & 20,00 \\
Sedang & $557-731$ & 11 & 73,33 \\
Rendah & $<557$ & 1 & 6,67 \\
\hline
\end{tabular}

Pada tabel diatas, dapat diketahui bahwa peserta didik perempuan yang berada pada kategorisasi tinggi dengan persentase $20 \%$ atau sebanyak 3 orang. Adapun skor total yang termasuk kedalam kategori ini adalah peserta didik yang memiliki skor diatas 731 atau berbeda 20 poin lebih tinggi jika dibandingkan dengan skor total laki-laki untuk yang termasuk dalam kategori tinggi. Hal ini menunjukkan bahwa perempuan memiliki rata-rata skor yang lebih tinggi jika dibandingkan dengan peserta didik laki-laki.

Peserta didik perempuan yang termasuk dalam kategori sedang berjumlah 11 orang atau sebesar $73,33 \%$. Adapun capaian skor yang termasuk dalam kategori ini antara 557-731 poin. Hal ini menunjukkan bahwa rata-rata skor total peserta didik perempuan lebih tinggi jika dibandingkan dengan peserta didik laki-laki. Sementara itu, peserta didik perempuan yang berada dalam kategori rendah sejumlah 1 orang atau sebesar $6,67 \%$. Sementara itu, jumlah skor total peserta didik perempuan yang termasuk kedalam kategori ini adalah dibawah 557 poin.

Secara keseluruhan, jumlah ratarata peserta didik perempuan lebih tinggi jika dibandingkan dengan peserta didik laki-laki. Peserta didik perempuan memiliki skor rata-rata sebesar 643,6 poin, sementara peserta didik laki-laki hanya mendapatkan skor rata-rata 627,86. Kategorisasi konsep diri akademik peserta didik perempuan dapat dilihat pula pada grafik dibawah ini:

Grafik 2

Persentase Konsep Diri Akademik Peserta Didik

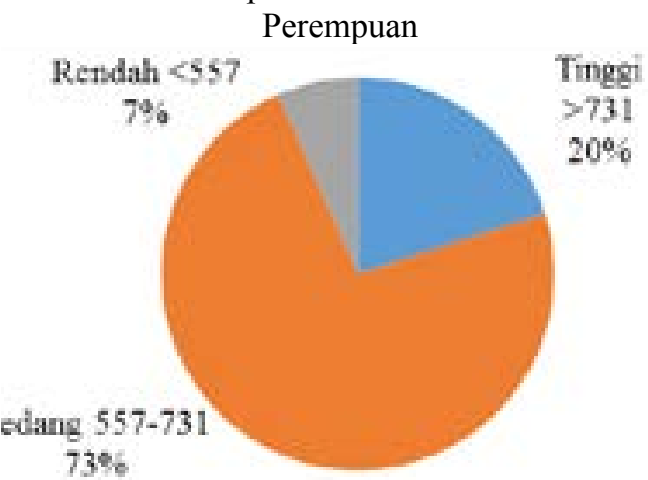

Secara keseluruhan, jumlah rata-rata peserta didik perempuan lebih tinggi jika dibandingkan dengan peserta didik laki-laki. Peserta didik perempuan memiliki skor ratarata sebesar 643,6 poin, sementara peserta didik laki-laki hanya mendapatkan skor ratarata 627,86 . Hal ini menunjukkan bahwa peserta didik perempuan memiliki konsep diri akademik lebih baik dibandingkan dengan peserta didik laki-laki berdasarkan skor rata-rata yang diperoleh.

Peserta didik yang termasuk dalam kategori konsep diri akademik tinggi diindikasikan dengan kemampuan belajar yang baik, motivasi untuk belajar juga baik, pencapaian akademik juga baik. Kemampuan belajar yang baik ditunjukkan dengan daya serap pada setiap pelajaran atau materi yang disampaikan oleh pengajar sangat baik. Peserta didik dapat menyimak dan mengikuti pelajaran dengan cepat, selain itu peserta didik juga dapat menjawab pertanyaan yang diajukan oleh pengajar. Pada peserta didik laki-laki, kemampuan belajar mereka sangat 
baik untuk bidang-bidang eksakta seperti Matematika dan Fisika, sedangkan pada peserta didik perempuan lebih cenderung memiliki kemampuan belajar yang baik pada bidang-bidang non-eksakta terutama bidang bahasa seperti Bahasa Indonesia dan Bahasa Inggris.

Peserta didik yang termasuk dalam kategori konsep diri akademik sedang atau rata-rata, diindikasikan dengan kemampuan akademik berada pada batas standar, motivasi belajar juga tidak terlalu tinggi dan tidak terlalu rendah, serta pencapaian akademik yang tidak jauh berada diatas nilai standar minimal. Kemampuan akademik pada batas standar ditunjukkan dengan daya serap pada materi pelajaran di kelas lebih lambat dibandingkan peserta didik dengan konsep diri akademik tinggi, namun lebih cepat jika dibandingkan peserta didik dengan konsep diri akademik rendah.

Kemampuan akademik yang dimiliki oleh peserta didik dengan konsep diri akademik rendah memang dibawah standar yang ada. Peserta didik ini butuh perhatian khusus terutama dalam penambahan jam belajar, dikarenakan mereka membutuhkan waktu lebih lama untuk menyerap pelajaran atau materi yang diberikan oleh pengajar. Primagama perlu memberikan waktu belajar tambahan bagi peserta didik yang termasuk dalam kategori konsep diri akademik rendah ini agar mereka dapat meningkatkan kemampuan akademiknya sehingga dapat bersaing dengan peserta didik lainnya yang memiliki konsep diri akademik lebih baik.

Tinggi atau rendahnya skor ratarata konsep diri akademik peserta didik dipengaruhi oleh pengalaman pribadi dan interaksi dengan lingkungannya. Peserta didik yang memiliki konsep diri akademik dalam kategori tinggi dapat dikatakan bahwa peserta didik tersebut memiliki pengalaman pribadi mengenai bidang-bidang akademik yang cukup baik. Misalnya saja pada peserta didik yang dilahirkan dari keluarga yang memiliki pendidikan yang baik, peserta didik tersebut sejak kecil akan dididik dalam iklim akademik yang baik, sehingga membuat peserta didik memiliki cara pandang yang baik terhadap akademik.

Selain itu, peserta didik yang berinteraksi dengan lingkungan yang memiliki kesadaran akademik yang baik, akan mempengaruhi konsep diri peserta didik tersebut. Misalnya saja pada peserta didik yang tidak dilahirkan dari orangtua yang memiliki kemampuan akademik yang baik, akan tetapi orang-orang yang tinggal di sekitar rumah peserta didik memiliki kemampuan akademik yang baik. Sehingga secara tidak langsung akan membuat peserta didik berinteraksi dengan tetangga dan kemudian kemampuan akademik serta konsep diri peserta didik terhadap akademiknya akan berkembang dengan baik. Begitu pula sebaliknya, apabila lingkungan sekitar tempat tinggal peserta didik memiliki kemampuan akademik yang kurang baik, hal ini akan mempengaruhi kemampuan dan konsep diri peserta didik terhadapnya akademiknya. Lingkungan disini tidak hanya lingkungan rumah, tetapi juga lingkungan sekolah. Karena ketika berada di sekolah, peserta didik berinteraksi dengan peserta didik lain yang memiliki latar belakang keluarga yang berbeda-beda, sehingga hal ini juga berpengaruh pada konsep diri akademik peserta didik.

\section{KESIMPULAN DAN SARAN}

Kesimpulan secara umum bahwa peserta didik perempuan memperoleh skor rata-rata 643,6 dari 15 peserta didik dan peserta didik laki-laki memperoleh skor ratarata 627,86 dari 22 peserta didik. Peserta didik laki-laki yang termasuk dalam kategori konsep diri akademik tinggi sejumlah 4 orang atau sebesar $18,18 \%$, sedangkan peserta didik yang memiliki konsep diri akademik dalam kategori sedang sejumlah 15 orang atau sebesar $68,18 \%$. Sementara itu peserta didik yang memiliki konsep diri akademik rendah sejumlah 3 orang atau sebesar 13,64\%.

Peserta didik perempuan yang memiliki konsep diri akademik tinggi terdapat 3 orang atau sekitar $20 \%$ dari jumlah 
total peserta didik perempuan. Sementara itu, peserta didik perempuan yang memiliki konsep diri akademik sedang sejumlah 11 orang atau sekitar $73,33 \%$ dari jumlah total peserta didik perempuan. sedangkan peserta didik perempuan yang memiliki konsep diri akademik rendah terdapat 1 orang peserta didik atau sebesar $6,67 \%$ dari jumlah total peserta didik perempuan.

Peneliti berharap pengajar BK di Primagama lebih memperhatikan konsep diri akademik yang dimiliki oleh peserta didik. Karena apabila pengajar BK lebih memperhatikan konsep diri yang dimiliki oleh peserta didik, akan lebih membantu pengajar BK dalam menyampaikan layanan bimbingan klasikal di kelas yang berkaitan dengan akademik peserta didik. Pengajar BK juga harus memperhatikan peserta didik dengan konsep diri akademik yang rendah agar proses belajar peserta didik tersebut di Primagama dapat berjalan dengan baik.

Peneliti berharap agar Kepala Cabang Primagama Kampung Makasar juga memperhatikan konsep diri akademik yang dimiliki peserta didik. Hal ini bertujuan agar proses penyampaian materi di lembaga bimbingan belajar dapat disesuaikan dengan karakteristik peserta didiknya sehingga lebih tepat sasaran. Selain itu, agar proses belajar lebih optimal dan peserta didik lebih dapat menyerap materi yang disampaikan dengan baik, maka Primagama Kampung Makasar perlu memberikan materi tambahan diluar jam belajar wajib kepada peserta didik yang memiliki konsep diri akademik rendah. Kemudian metode dalam penyampaian materi juga harus lebih diperhatikan dan lebih bervariasi agar peserta didik tidak mengalami kejenuhan selama pelajaran berlangsung, karena apabila peserta didik yang memiliki konsep diri akademik rendah diberikan materi yang cara penyampaiannya sama dengan peserta didik yang memiliki konsep diri akademik tinggi, maka peserta didik akan mengalami kebosanan dalam belajar. Hal ini akan berdampak pada peserta didik yang enggan untuk mengikuti proses belajar di Primagama Kampung Makasar.
Peneliti menyarankan kepada peneliti lain yang hendak melakukan penelitian terkait konsep diri akademik, agar melakukan penelitian dengan cakupan peserta didik lebih luas lagi. Selain itu, peneliti lain juga dapat melakukan korelasi antara skor konsep diri akademik dengan skor capaian hasil belajar.

\section{DAFTAR PUSTAKA}

Bacon, L.S.C. (2011). Academic self-concept and academic achievement of African American students transitioning from urban to rural schools. PhD (Doctor of Philosophy) thesis, University of Iowa

Burns, R.B.(1982). Self-concept Development and Education. Dorchester: Dorset Press.

Marsh, H.W. (1990). The structure of academic self-concept: The marsh/ shavelson model. Journal of Education Phychology, 82(4), 623-636.

Marsh, H.W. (1992). Content specificity of relation between academicachievement and academic self-concept. Journal of Education Psychology, 84(1), 35-42.

Rosen, J.A. (2010). Noncognitive skills in the Classroom: New Perspectives on Educational Research. New York: Research Triangle Park.

Shavelson, R.J., Bolus, R. (1982). Selfconcept: the interplay of theory and methods. Journal of Educational Psychology, 74(1), 3-17 
